\title{
Alteration of Water Absorption Coefficient of Spruce (Picea abies (L.) Karst.) due to Thermal Modification
}

\section{Promjena koeficijenta upijanja vode smrekovine (Picea abies (L.) Karst.) zbog njezine termičke modifikacije}

\author{
Professional paper • Stručni rad \\ Received-prispjelo: 2. 3. 2011. \\ Accepted-prihvaćeno: 22. 11. 2011. \\ UDK: $630 * 812.22 ; 630 * 812.463$ \\ doi:10.5552/drind.2011.1109
}

\begin{abstract}
The aim of the investigations was to evaluate the influence of a thermal modification on the water absorption behaviour of spruce (Picea abies (L.) Karst.). After recording the water uptake of wood samples by partial immersion, a water absorption coefficient of the material could be determined according to EN ISO 15148:2002. The thermal modification results in an alteration of the water absorption behaviour in dependence on the sectional area. In radial and tangential direction the water absorption decreases with the modification. In contrast, in longitudinal direction the water uptake increases.
\end{abstract}

Key words: anisotropy, thermal modification, water absorption coefficient

SAŽETAK • Cilj istraživanja bio je procijeniti utjecaj termičke modifikacije smrekovine (Picea abies (L.) Karst.) na svojstvo upijanja vode. Bilježenjem količine vode što ju upiju drvni uzorci nakon njihova djelomičnog uranjanja može se, prema normi EN ISO 15148:2002, odrediti koeficijent upijanja vode. Termičkom modifikacijom drva mijenja se svojstvo upijanja vode u ovisnosti o površini presjeka drva. U radijalnome i tangencijalnom smjeru upijanje vode se smanjuje u modificiranog drva. Suprotno tomu, u uzdužnom se smjeru upijanje vode povećava.

Ključne riječi: anizotropnost, termička modifikacija, koeficijent upijanja vode

\section{INTRODUCTION}

1. UVOD

Moisture movement in a hygroscopic capillaryporous material is a combination of moisture vapor and liquid transport. These are related to the pressure, tem- perature and moisture gradients and the properties of the materials in a complex interrelationship.

The steady-state (e.g. Popper et al, 2005) and the unsteady-state (e.g. Pfriem et al, 2007; Pfriem et al, 2010) sorption behavior of thermally modified wood is well studied. Thermal degradation of hemicelluloses

\footnotetext{
${ }^{1}$ The author is professor at Faculty of Wood Science and Technology, Eberswalde University for Sustainable Development - University of Applied Sciences, Eberswalde, Germany.

'Autor je profesor Fakulteta za znanost o drvu i tehnologiju Sveučilišta primijenjenih znanosti, Eberswalde, Njemačka.
} 
leads to a reduction of hydroxyl groups and to a reduced number of intra- and intermolecular hydrogen bonds (Pfriem, 2006; Boonstra and Tjeerdsma, 2006; Windeisen et al, 2007). For this reason, the equilibrium wood moisture of thermally modified wood is lower and the sorption isotherms show a reduction of the sorption capacity (Popper et al, 2005). Metsä-Kortelainen et al. (2006) determined the alteration of water absorption of sapwood and heartwood of Scots pine $(P i$ nus sylvestris L.) and Norway spruce (Picea abies (L.) Karst.) due to thermal modification in a floating test. They found that the higher the modification temperature, the lower the amount of absorbed moisture.

The aim of the present investigation was to evaluate the intensity of the absorption of water due to capillary forces and their alteration due to thermal modification.

\section{MATERIALS AND METHODS 2. MATERIJALI I METODE}

Spruce (Picea abies (L.) Karst.) was analyzed. The thermal modification was performed in a single stage dry process - patented by the company Mühlböck (Austria) - at $180{ }^{\circ} \mathrm{C}$ in a commercial plant at Mitteramskogler $\mathrm{GmbH}$ in Gaflenz (Austria). In this process, the exhaust volatile gases and remaining oxygen are removed from the reaction chamber and burnt off externally. The treatment duration was $4 \mathrm{~h}$ (Pfriem 2006).

The dimension of the specimens was $100 \mathrm{~mm} \mathrm{x}$ $100 \mathrm{~mm}$ (parallel and tangential to the axis) and $20 \mathrm{~mm}$ (radial). The modified and unmodified specimens were conditioned at $23{ }^{\circ} \mathrm{C}$ and $\mathrm{RH} 60 \%$. Water absorption tests were performed according to EN ISO 15148:2002 by partial immersion for short periods of time and without temperature gradient in dependence on the main cutting direction cross-section, tangential and radial section. It is used to assess the intensity of water absorption via the wood capillary system. To restrict moisture transport to one direction the non-tested surfaces of the specimens were sealed with epoxy resin and aluminum foil. For the study of capillary water absorption the non-sealed surface of a specimen was partially immersed in water. Therefore, the samples have been placed in a water basin. The water level was kept constant at $10 \mathrm{~mm}$ above the bottom of the sample. The test lasts 24 hours, with at least three specimens.
The specimens are periodically removed, the surfaces are wiped, the specimens are weighed, and again partially immersed in the water. The mass of water absorbed per unit area of specimen surface is plotted against the square root of time. In accordance to EN ISO 15148:2002 the water absorption coefficient $A_{\mathrm{w}}$ describes the time-dependent water absorption of the material. The first derivative of the change in mass plotted against the square root of time is used for the calculation of $A_{\text {w }}$

\section{RESULTS, DISCUSSION AND CONCLUSIONS}

3. REZULTATI, DISKUSIJA I ZAKLJUČCI

The rate of liquid water absorption in wood depends on several factors. There are clear differences in water absorption coefficient in the three main directions (Table 1). Due to the capillary action of the cells, the rate of absorption is most rapid in longitudinal direction. In radial direction the water uptake may be partly taking place about the rays, resulting in higher water absorption than in tangential direction.

In radial and tangential direction, thermally modified samples show a reduction in the capillary water absorption compared to the native specimens. As the wood becomes more hydrophobic, its wettability by water decreases as shown by contact angle measurements by Kocaefe et al. (2008) or Metsä-Kortelainen and Viitanen (2011).

It is remarkable that the thermal modification increases the capillary water uptake in longitudinal direction. This is partly in contradiction to the work of Bächele et al. (2004) or Krause and Militz (2004).

One explanation for this abnormal behavior is the increase of porosity of the wood by the thermal modification. Our own studies using helium pycnometry and mercury intrusion porosimetry have shown that there are quantitative differences in the true density and pore structure depending on wood species and intensity of the thermal modification (Pfriem et al, 2009).

The determined parameters can contribute to describe the ability of the capillary water transport in wood. The effect of increased water uptake must be considered particularly in the use of thermally modified wood in structures, if the cross-sectional areas are exposed to water.

Table1 Water absorption coefficient of thermally modified and unmodified spruce (standard deviation in brackets)

Tablica 1. Koeficijent upijanja vode termički modificirane i nemodificirane smrekovine (standard devijacije u zagradama)

\begin{tabular}{|c|c|c|c|}
\hline \multirow[b]{2}{*}{$\begin{array}{l}\text { Wood section } \\
\text { Presjek drva }\end{array}$} & \multicolumn{3}{|c|}{$\begin{array}{c}\text { Water absorption coefficient } \boldsymbol{A}_{\mathrm{w}} \text { in } \mathbf{k g} /\left(\mathbf{m}^{2} \cdot \mathbf{h}^{\mathbf{1} / \mathbf{2}}\right) \\
\text { Koeficijent upijanja vode } A_{w} \mathrm{u} \mathrm{kg} /\left(\mathrm{m}^{2} \cdot \mathrm{h}^{1 / 2}\right)\end{array}$} \\
\hline & $\begin{array}{c}\text { Spruce, unmodified } \\
\text { Nemodificirana smrekovina }\end{array}$ & $\begin{array}{c}\text { Spruce, thermally } \\
\text { modified } \\
\text { Termički modificirana } \\
\text { smrekovina }\end{array}$ & $\begin{array}{l}\text { Alteration } \\
\text { Promjena }\end{array}$ \\
\hline Cross-section / poprečni presjek & $0.615(0.004)$ & $0.808(0.006)$ & $31 \%$ \\
\hline Tangential section / tangencijalni presjek & $0.088(0.006)$ & $0.058(0.002)$ & $-34 \%$ \\
\hline Radial section / radijalni presjek & $0.108(0.015)$ & $0.099(0.004)$ & $-8 \%$ \\
\hline
\end{tabular}


Additionally, it has to be stated that the determined values do not contain information about the water content profiles that occur during the sorption process.

\section{REFERENCES}

\section{LITERATURA}

1. Bächle, F.; Niemz, P.; Junghans, K., 2004: Arbeiten zu thermisch vergütetem Holz, Vortrag, 2. Europäischer Thermoholztag, Dresden.

2. Boonstra, M.J.; Tjeerdsma, B., 2006: Chemical analysis of heat treated softwoods. Holz Roh Werkst. 64: 204-211, $\mathrm{http} / / / \mathrm{dx}$.doi.org/10.1007/s00107-005-0078-4

3. EN ISO 15148 2002: Hygrothermal performance of building materials and products - Determination of water absorption coefficient by partial immersion.

4. Krause, A.; Militz, H., 2004: Hitzebehandeltes Holz-Eigenschaften für den Fensterbau, Vortrag, 2. Europäischer Thermoholztag, Dresden.

5. Kocaefe, D.; Poncsak, S.; Doré, G.; Younsi, R., 2008: Effect of heat treatment on the wettability of white ash and soft maple by water. Holz Roh Werkst. 66: 355-361, http://dx.doi.org/10.1007/s00107-008-0233-9.

6. Metsä-Kortelainen, S.; Antikainen, T.; Viitaniemi, P., 2006: The water absorption of sapwood and heartwood of Scots pine and Norway spruce heat-treated at $170^{\circ} \mathrm{C}, 190$ ${ }^{\circ} \mathrm{C}, 210^{\circ} \mathrm{C}$ and $230{ }^{\circ} \mathrm{C}$. Holz Roh Werkst. 64: 192-197. http://dx.doi.org/10.1007/s00107-005-0063-y

7. Metsä-Kortelainen S.; Viitanen, H., 2011: Wettability of sapwood and heartwood of thermally modified Norway spruce and Scots pine Eur. J. Wood Prod. Online first: http://dx.doi.org/10.1007/s00107-011-0523-5.

8. Pfriem, A., 2006: Untersuchungen zum Materialverhalten thermisch modifizierter Hölzer für deren Verwendung im Musikinstrumentenbau. $\mathrm{PhD}$ thesis TU Dresden.

9. Pfriem, A.; Grothe, T.; Wagenführ, A., 2007: Einfluss der thermischen Modifikation auf das instationäre Sorption- sverhalten von Fichte (Picea abies (L.) Karst.). Holz Roh Werkst. 65: 321-323, http://dx.doi.org/10.1007/s00107-006-0167-z.

10. Pfriem, A.; Zauer, M.; Wagenführ, A., 2009: Alteration of the pore structure of spruce (Picea abies (L.) Karst.) and maple (Acer pseudoplatanus L.) due to thermal treatment as determined by helium pycnometry and mercury intrusion porosimetry. Holzforschung 63: 94-98, http://dx.doi.org/10.1515/HF.2009.027.

11. Pfriem, A.; Zauer, M.; Wagenführ, A., 2010: Alteration of the unsteady sorption behaviour of maple (Acer pseudoplatanus L.) and spruce (Picea abies (L.) Karst.) due to thermal modification. Holzforschung 64: 235-241, http://dx.doi.org/10.1515/HF.2010.029.

12. Popper, R.; Niemz, P.; Eberle, G., 2005: Untersuchungen zum Sorptions- und Quellungsverhalten von thermisch behandeltem Holz. Holz Roh Werkst. 63: 135-148, http://dx.doi.org/10.1007/s00107-004-0554-2.

13. Windeisen, E.; Strobel, C.; Wegener, G., 2007: Chemical changes during the production of thermo-treated beach wood. Wood Sci. Technol. 41: 523-536, http://dx.doi.org/10.1007/s00226-007-0146-5.

\section{Corresponding address:}

\section{Prof. Dr.-Ing. ALEXANDER PFRIEM}

Eberswalde University for Sustainable Development University of Applied Sciences Faculty of Wood Science and Technology Friedrich-Ebert-Straße 28 16225 Eberswalde, GERMANY e-mail: alexander.pfriem@hnee.de 